\title{
Analisis dan Pengembangan Sistem Self Services Terminal (SST) dengan Pendekatan PIECES pada STMIK Pradnya Paramita Malang
}

\author{
Indah Dwi Mumpuni, Weda Adistianaya Dewa
}

\begin{abstract}
Kebutuhan akan sistem informasi telah memberikan dampak atau pengaruh terhadap sebuah institusi atau organisasi. Bukan organisasi saja melainkan sampai dengan bisnis dan transaksi organisasi. Tujuan penelitian ini adalah untuk mengetahui kelayakan sebuah sistem dari Self Services Terminal (SST) dan berdasarkan analisis PIECES sehingga diketahui kekuatan dan kelemahan yang kemudian diperlukan pengembangan Self Services Terminal (SST) guna kemajuan STMIK Pradnya Paramita Malang. Metode PIECES yang terdiri dari Performance, Information/data, Economic (ekonomi), Control/security, Efficiency, Service. Metode penelitian yang digunakan adalah pengumpulan data dan pengembangan sistem. Hasil dari penelitian adalah adanya perbaikan, pengembangan berdasarkan analisis PIECES yang bermanfaat bagi seluruh pihak yang menggunakan SST. Berdasarkan Kuisioner yang dibagikan kepada 100 responden dengan kerangka kerja PIECES Sistem SST pada STMIK Pradnya Paramita Malang adalah baik dengan sebagian besar responden memberikan jawaban baik sebesar $47 \%$ dengan nilai 3,52, sedangkan masing-masing aspek yang terdiri dari pertama Aspek Performance (Kinerja) adalah baik dengan nilai 3,48, Kedua, aspek information (informasi) adalah baik dengan nilai 3,64, Ketiga, aspek economic (ekonomi) adalah cukup baik nilainya 3,08, Keempat, aspek control (kontrol) adalah baik dengan nilai 3,64, Kelima, aspek efficiency (Efisiensi) adalah baik dengan nilai 3,55 dan Keenam, aspek services adalah baik dengan nilai 3,69 .
\end{abstract}

Kata Kunci : Analisis, PIECES, Self Srvice Terminal (SST), STMIK Pradnya Paramita

Manuscript received Desember 22, 2016. This work was supported in part by Information System Department of STMIK Pradnya Paramita Malang.

Indah Dwi Mumpuni is with the Information System Department of STMIK Pradnya Paramita Malang; email indahstimata@yahoo.com)

Weda Adistianaya Dewa was with the Information System Department of STMIK Pradnya Paramita Malang; e-mail: wedadewa25@gmail.com).

\section{Pendahuluan}

Perkembangan teknologi yang semakin maju di era globalisasi seperti sekarang ini menuntut sumber daya manusia yang berkualitas dalam hal komputerisasi bagi semua kalangan, baik dari segi pendidikan maupun dalam dunia bisnis. Saat ini komputer juga dapat digunakan sebagai pengolahan data dalam dunia pendidikan, kesehatan, pemerintah, atau swasta maupun dalam bidang yang lainnya. Komputer juga dapat digunakan sebagai media pencarian informasi untuk mempermudah kerja dan kinerja orang yang menggunakannya. Informasi-informasi tersebut sangat mudah didapatkan melalui teknologi jaringan internet yang telah tersebar luas di dunia.

Jaringan internet merupakan sebuah jaringan komputer dalam skala global/ mendunia. Jaringan komputer ini dapat berskala international yang dapat membuat masing-masing komputer saling berkomunikasi satu dengan yang lainnya. Dengan internet pula manusia bisa mendapatkan informasi dan dapat saling berkomunikasi dimanapun mereka berada. Informasi yang terdapat di internet sangat mudah didapatkan melalui situs web.

Situs web telah banyak digunakan oleh berbagai macam pihak mulai dari instansi pemerintahan, lembaga pendidikan, perusahaan, praktisi media massa hingga setiap orang yang memiliki akses ke internet dapat menggunakannya selama 24 jam. Kegunaan situs web sangatlah beragam bisa digunakan sebagai media informasi, promosi, alat penjualan hingga dapat memberikan gambaran secara jelas bagi masyarakat tentang sebuah instansi atau lembaga. Bukan hanya itu situs web juga telah menjadi suatu sarana interaksi sosial masyarakat, situs-situs sosial seperti facebook, twitter, blog, dan situs sosial yang lainnya bisa memberikan kemudahan komunikasi bagi setiap penggunanya. Kemudahan komunikasi inilah yang dijadikan alasan oleh instansi pemerintah, perusahaan, lembaga pendidikan serta pengguna internet lainnya menggunakan situs web sebagai media komunikasi informasi kepada masyarakat.

Suatu perguruan tinggi yang baik haruslah memiliki satu situs web guna memberikan informasi kepada masyarakat tentang perguruan tinggi tersebut. 
Informasinya bisa berupa sejarah, visi dan misi, kompetensi, profil, serta informasi akademik yang ada pada perguruan tinggi tersebut. Dengan adanya informasi-informasi tersebut maka masyarakat dapat menilai kualitas dari perguruan tinggi dan juga bisa memberikan suatu kejelasan bagi mahasiswa yang belajar melalui sistem informasi akademik yang ada.

STMIK PPKIA Pradnya Paramita merupakan salah satu perguruan tinggi swasta yang ada di Malang Jawa Timur. STMIK PPKIA Pradnya Paramita menggunakan Sistem Informasi Akademik yang dikenal dengan Self Service Terminal (SST) yang dikembangkan oleh Puskom STIMATA yang dapat menyatukan semua informasi dari berbagai macam bagian menjadi satu informasi secara logical sehingga bisa mendapatkan informasi yang dibutuhkan secara mudah.

Self Service Terminal disingkat SST merupakan sebuah fasilias bagi Administrasi Umum (BAU). Sistem informasi akademik yang ada pada STMIK PPKIA Pradnya Paramita Malang memungkinkan mahasiswa untuk melihat dan mengolah data-data perkuliahan mereka. Data-data tersebut antara lain berupa biodata mahasiswa, sebaran matakuliah, informasi mahasiswa untuk melakukan aktifitas pra akademik dan past akademik, seperti: melihat dan mengedit KRS, melihat KHS, melihat salinan nilai, memperbarui biodata mahasiswa dan melihat pengumuman terbaru dari Bagian Administrasi Akademik (BAAK) dan Bagian transkrip nilai, informasi KHS (Kartu Hasil Studi),informasi dan pengisian KRS (Kartu Rencana Studi). Semua data-data tersebut, mahasiswa dapat melihat dan mengakses melalui situs sst.stimata.ac.id dengan laman online Self Service Terminal (SST) STMIK PPKIA Pradnya Paramita dengan sangat mudah. Walaupun demikian bukan berarti situs web yang menangani Self Service Terminal online di STMIK PPKIA Pradnya Paramita tidak memiliki kekurangan, akan tetapi perlu adanya analisis dengan pendekatan metode[2]. Metode ini menggunakan enam variable evaluasi yaitu :1) Performance (kinerja) Menilai apakah proses atau prosedur yang ada masih mungkin ditingkatkan kinerjanya. 2) Information (informasi) Menilai apakah prosedur yang ada saat ini masih dapat diperbaiki sehingga kualitas informasi yang dihasilkan menjadi semakin baik. 3) Economic (ekonomi) Menilai apakah prosedur yang ada saat ini masih dapat ditingkatkan manfaatnya (nilai gunanya) atau diturunkan biaya penyelenggaraannya. 4) Control (pengendalian) Menilai apakah prosedur yang ada saat ini masih dapat ditingkatkan 5) Efficiency (efisiensi) Menilai apakah prosedur yang ada saat ini masih dapat diperbaiki, sehingga tercapai peningkatan efisiensi operasi. 6) Service (layanan) Menilai apakah prosedur yang ada saat ini masih dapat diperbaiki kemampuannya untuk mencapai peningkatan kualitas layanan. Sehingga dalam hal ini perlu dianalisis kelayakan dari sistem yang sudah ada agar meningkatkan kualitas pelayanan dan pengembangan akademik.

\section{A. Rumusan Masalah}

Berdasarkan uraian dari latar belakang di atas maka dapat dirumuskan masalah yang timbul pada objek penelitian adalah "Bagaimana menganalisis dan mengembangkan sistem Self Service Terminal (SST) dengan pendekatan PIECES pada STMIK PPKIA Pradnya Paramita Malang?

\section{B. Tujuan}

Tujuan yang dicapai adalah Tujuan yang akan dicapai adalah untuk mengetahui kelayakan sebuah sistem dari Self Service Terminal (SST) dan berdasarkan analisis PIECES sehingga diketahui kekuatan dan kelemahan yang kemudian diperlukan pengembangan Self Service Terminal (SST) guna kemajuan STMIK Pradnya Paramita Malang.

\section{Batasan Masalah}

Batasan Masalah dalam penelitian ini adalah sebagai berikut :

1. Analisis Sistem SST dengan menggunakan pendekatan PIECES yang terdiri dari aspek performance, information, ecoconomic, control, efficiency dan services.

2. Desain Sistem pengembangan SST berdasarkan pendekatan PIECES.

\section{LANDASAN TEORI}

\section{A. Metode Analisis}

Metode Analisis yang digunakan adalah metode PIECES \Metode PIECES adalah metode analisis sebagai dasar untuk memperoleh pokok-pokok permasalahan yang lebih spesifik[2]. Dalam menganalisis sebuah sistem, biasanya akan dilakukan terhadap beberapa aspek antara lain adalah kinerja, informasi, ekonomi, keamanan aplikasi, efisiensi dan pelayanan pelanggan. Analisis ini disebut dengan PIECES Analisis (Performance, Information, Economy, Control, Eficiency and Service). Analisis PIECES ini sangat penting untuk dilakukan sebelum mengembangkan sebuah sistem informasi karena dalam analisis ini biasanya akan ditemukan beberapa masalah utama maupun masalah yang bersifat gejala dari masalah utama. Metode ini menggunakan enam variable evaluasi yaitu :

\section{Performance (kinerja)}

Kinerja merupakan variable pertama dalam metode analisis PIECES. Dimana memiliki peran penting untuk menilai apakah proses atau prosedur yang ada masih mungkin ditingkatkan kinerjanya, dan melihat sejauh mana dan seberapa handalkah suatu sistem informasi dalam berproses untuk menghasilkan tujuan yang diinginkan. Dalam hal ini kinerja diukur dari:

a) throughput, yaitu jumlah pekerjaan /output /deliverables yang dapat dilakukan/ dihasilkan pada saat tertentu.

b) response time, yaitu waktu yang dibutuhkan untuk menyelesaikan serangkaian kegiatan untuk menghasilkan output/deliverables tertentu.

\section{Information (informasi)}

Menilai apakah prosedur yang ada saat ini masih dapat diperbaiki sehingga kualitas informasi yang dihasilkan menjadi semakin baik. Informasi yang disajikan haruslah benar-benar mempunyai nilai yang berguna. 
Hal ini dapat diukur dengan :

a) Keluaran ( Outputs ) : Suatu sistem dalam memproduksi keluaran.

b) Masukan ( Inputs ) : Dalam memasukkan suatu data sehingga kemudian diolah untuk menjadi informasi yang berguna.

3. Economic (ekonomi)

Menilai apakah prosedur yang ada saat ini masih dapat ditingkatkan manfaatnya (nilai gunanya) atau diturunkan biaya penyelenggaraannya.

4. Control (pengendalian)

Menilai apakah prosedur yang ada saat ini masih dapat ditingkatkan sehingga kualitas pengendalian menjadi semakin baik, dan kemampuannya untuk mendeteksi kesalahan/kecurangan menjadi semakin baik pula.

\section{Efficiency (efisiensi)}

Menilai apakah prosedur yang ada saat ini masih dapat diperbaiki, sehingga tercapai peningkatan efisiensi operasi, dan harus lebih unggul dari pada sistem manual.

\section{Service (layanan)}

Menilai apakah prosedur yang ada saat ini masih dapat diperbaiki kemampuannya untuk mencapai peningkatan kualitas layanan. Buatlah kualitas layanan yang sangat user friendly untuk end - user (pengguna) sehingga pengguna mendapatkan kualitas layanan yang baik.

PIECES Framework adalah kerangka yang dipakai untuk mengklasifikasikan suatu problem, opportunities, dan directives yang terdapat pada bagian scope definition analisa dan perancangan sistem. Dengan kerangka ini, dapat dihasilkan hal-hal baru yang dapat menjadi pertimbangan dalam pengembangan sistem. Metoda PIECES yang terdiri dari Performance, Information/data, Control/security, Efficiency, Service. Masing-masing kategori tersebut dapat dibagi lagi menjadi beberapa kriteria.

\section{Performance}

Kinerja adalah suatu kemampuan sistem dalam menyelesaikan tugas dengan cepat sehingga sasaran dapat segera tercapai. Berikut indikator-indikator yang dapat menunjukkan kinerja suatu sistem informasi :

a. throughput, dimana sistem dinilai dari banyaknya

kerja yang dilakukan pada beberapa periode waktu.

b. respon time, yaitu delay rata-rata antara transaksi dan respon dari transaksi tersebut.

c. audibilitas, yaitu kecocokan dimana keselarasan terhadap standar dapat diperiksa.

d. kelaziman komunikasi, yaitu tingkat dimana interface standar, protokol, dan bandwith digunakan.

e. kelengkapan, yaitu derajat dimana implementasi penuh dari fungsi yang diharapkan tercapai.

f. konsistensi, yaitu penggunaan desain dan teknik dokumentasi yang seragam pada keseluruhan proyek pengembangan perangkat lunak.

f. konsistensi, yaitu penggunaan desain dan teknik dokumentasi yang seragam pada keseluruhan proyek pengembangan perangkat lunak.

g. toleransi kesalahan, yaitu kerusakan yang terjadi pada saat program mengalami kesalahan.

2. Information/data
Informasi merupakan hal penting karena dengan informasi tersebut pihak manajemen dan user dapat melakukan langkah selanjutnya. Apabila kemampuan sistem informasi baik, maka user akan mendapatkan informasi yang akurat, tepat waktu dan relevan sesuai dengan yang diharapkan.

a. accuracy (akurat), dimana informasi yang dihasilkan memiliki ketepatan yang tinggi.

b. relevansi informasi, dimana informasi yang dihasilkan sesuai dengan kebutuhan.

c. penyajian informasi, dimana informasi disajikan dalam bentuk yang sesuai dan mudah diintepretasikan.

d. fleksibilitas data, dimana informasi mudah disesuaikan dengan kebutuhan.

3. Economic

Pemanfaatan biaya yang digunakan dari pemanfaatan informasi. Peningkatan terhadap kebutuhan informasi yang ekonomis dapat mempengaruhi pengendalian biaya dan peningkatan manfaat terhadap sistem informasi.

a. reusabilitas, tingkat dimana sebuah program atau bagian dari program tersebut dapat digunakan kembali di dalam aplikasi yang lain.

b. sumber daya, jumlah sumber daya yang digunakan dalam pengembangan sistem, meliputi sumber daya manusia serta sumber daya ekonomi.

\section{Control}

Analisis ini digunakan untuk membandingkan sistem yang dianalisa berdasarkan pada segi integritas sistem, kemudahan akses, dan keamanan data.

a. integritas, tingkat dimana akses ke perangkat lunak atau data oleh orang yang tidak berhak dapat dikontrol.

b. keamanan, yaitu mempunyai mekanisme yang mengontrol atau melindungi program.

5. Efficiency

Efisiensi berhubungan dengan bagaimana sumber tersebut dapat digunakan secara optimal. Operasi pada suatu perusahaan dikatakan efisien atau tidak biasanya didasarkan pada tugas dan tanggung jawab dalam melaksanakan kegiatan.

a. usabilitas, usaha yang dibutuhkan untuk mempelajari, mengoperasikan, menyiapkan input, dan mengintepretasikan output suatu program.

b. maintanabilitas, usaha yang diperlukan untuk mencari dan membetulkan kesalahan pada sebuah program.

6. Service

Peningkatan pelayanan memperlihatkan kategori yang beragam. Peningkatan pelayanan yang lebih baik bagi manajemen, user dan bagian lain merupakan simbol kualitas dari suatu sistem informasi.

a. akurasi, yaitu ketelitian komputasi dan control.

b. reliabilitas, tingkat dimana sebuah program dapat dipercaya melakukan fungsi yang diminta.

c. kesederhanaan, yaitu tingkat dimana sebuah program dapat dipahami tanpa kesukaran.

\section{B. Data Flow Diagram (DFD)}

Data Flow Diagram (DFD) atau dalam bahasa Indonesia menjadi Diagram Alir Data (DAD) adalah representasi grafik yang menggambarkan aliran informasi dan transformasi informasi yang diaplikasikan 
sebagai data yang mengalir dan masukan (input) dan keluaran (output)[3].

DFD dapat digunakan untuk merepresentasikan sebuah sistem atau perangkat lunak untuk merepresentasikan sebuah sistem atau perangkat lunak pada beberapa level abstraksi. DFD dapat dibagi menjadi beberapa level yang lebih detail untuk merepresentasikan aliran informasi atau fungsi yang lebih detail. DFD menyediakan mekanisme untuk permodelan fungsional ataupun permodelan aliran informasi. Oleh karena itu, DFD lebih sesuai digunakan untuk memodelkan fungsi-fungsi perangkat lunak yang akan diimplementasikan menggunakan pemrograman terstruktur karena pemrograman terstruktur membagibagi bagiannya dengan fungsi-fungsi dan prosedurprosedur.

\section{Penelitian Terdahulu}

Penelitian atau pembahasan mengena analisis dan pengembangan sistem informasi dengan menggunakan pendekatan PIECES adalah sebagai berikut :

1. Evaluasi penerapan sistem informasi pada politeknik LP3I Jakarta dengan metode PIECES. Hasil wawancara dan kuesioner terhadap responden pengguna mahasiswa di tiga kampus penyelenggara. Pihak manajemen Politeknik LP3I Jakarta juga harus segera memberikan pelatihan dan sosialisai kepada mahasiswanya agar sistem informasi dapat mudah digunakan dan dimanfaatkan oleh para pengguna mahaiswa[4].

2. Perancangan sistem akuntansi penjualan tunai terkomputerisasi pada AL ISHBA Karpet. Penelitian ini bertujuan untuk (1) Mengetahui system akuntansi penjualan tunai yang diterapkan pada Al Ishba Karpet, (2) Merancang system akuntansi penjualan tunai terkomputerisasi yang sesuai dengan kebutuhan Al Ishba Karpet. Berdasarkan analisis PIECES, system yang baru memberi keuntungan dan manfaat lebih besar dari sistem yang lama. Berdasarkan analisis kebutuhan sistem, kebutuhan untuk mengembangkan sistem baru dapat dipenuhi baik secara fungsional maupun non fungsional. Berdasarkan analisis kelayakan sistem, sistem ini layak secara teknis, operasional, ekonomi, dan hukum. Desain sistem akuntansi penjualan tunai yang dirancang terdiri dari lima tabel, delapan form dan tiga laporan. Implementasi sistem akuntansi penjualan tunai terkomputerisasi menunjukkan bahwa system dapat berjalan baik. Sistem yang dirancang mempermudah perusahaan dalam mengolah transaksi penjualan dan meminimalisir kesalahan yang dilakukan oleh manusia. Keterbatasan sistem yang dirancang yaitu sistem tersebut hanya bisa diterapkan pada perusahaan Al Ishba Karpet saja, karena disesuaikan dengan kondisi perusahaan tersebut[5].

3. Evaluasi implementasi sistem electronic health record (ehr) di rumah sakit akademik Universitas Gadjah Mada berdasarkan metode analisis pieces. Tujuan penelitian ini adalah melakukan evaluasi sistem electronic health record (EHR) di Rumah Sakit Akademik Universitas Gadjah Mada ditinjau berdasarkan metode analisis PIECES untuk mengetahui aspek performance, information/data, economic, control, efficiency, dan service. Penelitian ini menggunakan metode penelitian deskriptif dengan pendekatan kuantitatif dan rancangan penelitian cross sectional. Hasil penelitian menunjukkan Aspek performance (kinerja), information/data (informasi/data), efficiency (efisiensi), service (layanan) sistem EHR di RS Akademik UGM dinilai baik oleh pengguna sistem EHR, sedangkan aspek control/security (kontrol/keamanan) dinilai cukup baik dan aspek economic (ekonomi) sistem EHR di RS Akademik UGM dinilai kurang baik oleh pengguna sistem EHR. Sedangkan sistem EHR di RS Akademik UGM apabila ditinjau dari karakteristik pengguna dengan berbagai kategori usia, pendidikan terakhir, masa kerja, dan unit kerja menunjukkan hasil yang berbeda dalam setiap aspek yang diteliti (performance, information/data, economic, control/security, efficiency, service)[1].

\section{Metode PenELITIAN}

Tahapan rancangan penelitian yang dilakukan : 1. Identifikasi dan Analisis Kebutuhan.

Kegiatan yang dilakukan pada tahap ini adalah melakukan observasi terhadap permasalahan yang sedang berjalan, studi literatur untuk mengetahui dan memahami dasar teori dan konsep-konsep yang mendukung dalam penelitian seperti (buku, jurnal, artikel) serta melakukan wawancara dengan pihak yang terkait yaitu mahasiswa, dosen serta bagian data.

2. Pengembangan dari Sistem SST.

Berdasarkan identifikasi dan analisis terhadap SST dengan pendekatan PIECES didapatkan kelemahankelemahan sehingga perlu dikembangkan sistem tersebut guna peningkatan kualitas SST STMIK PPKIA Pradnya Paramita.

\section{HASIl DAN PEMBAHASAN}

Aspek PIECES terdiri dari Performance, Information, Economy, Control, Efficiency, serta Service. Persepsi Pengguna Sistem SST Berdasarkan Aspek PIECES Tingkat aspek PIECES sistem SST di STMIK Pradnya Paramita Malang dalam penelitian ini diukur dengan instrumen angket (kuesioner) yang terdiri dari 20 item pertanyaan dengan skor 1 sampai dengan 5 (skala Likert) seperti pada tabel 1 sebagai berikut :

Tabel 1. Rentang Skor Jawaban

\begin{tabular}{|c|c|c|}
\hline No & Kategori Jawaban & Rentang Skor \\
\hline 1 & Sangat Baik & 4,201 s.d 5,000 \\
\hline 2 & Baik & 3,401 s.d 4,200 \\
\hline 3 & Cukup Baik & 2,601 s.d 3,400 \\
\hline 4 & Kurang Baik & 1,801 s.d 2,600 \\
\hline 5 & Tidak Baik & 1,000 s.d 1,800 \\
\hline
\end{tabular}

Berikut adalah penjelasan masing-masing aspek PIECES beserta distribusi hasil kuisioner dan rata-rata serta persepsinya, seperti pada tabel-tabel sebagai berikut : 
Tabel 2. Aspek Performance

\begin{tabular}{|c|c|c|c|c|c|}
\hline Ho & molatar & Defisisioperinal & 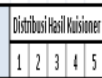 & & Pespap \\
\hline & mongte & 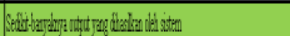 & 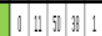 & 38 & Oungbix \\
\hline & Bgming & 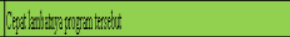 & 0164.4 & 33 & Ouphail \\
\hline & ing & 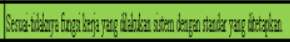 & 4866 & $32 \pi$ & 踏 \\
\hline 4 & 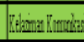 & 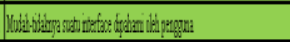 & 1539511 & 367 & gak \\
\hline & Pentrita & 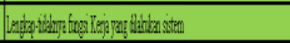 & $012: 17 \mid 4$ & 3.60 & 粲 \\
\hline 6 & Frimber & 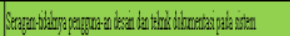 & 17139217 & 39 & gak \\
\hline 1 & Titrailladitin & Sirit & $0.12: 37 \mid$ & 3.2 & Ohapbit \\
\hline
\end{tabular}

Berdasarkan tabel 2 hasil rata-ratanya 3,48 adalah baik.

Tabel 3. Aspek Information

\begin{tabular}{|c|c|c|c|c|c|c|c|c|c|}
\hline \multirow{2}{*}{$\mathbb{H}$} & \multirow{2}{*}{ Inthatur } & \multirow{2}{*}{ Definsiopersionel } & \multicolumn{5}{|c|}{ 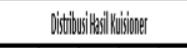 } & & \multirow{2}{*}{ Pespepii } \\
\hline & & & 1 & 2 & 3 & 4 & 5 & & \\
\hline & Hras & 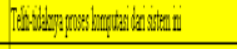 & 1 & 11 & 3 & . & 6 & 351 & bik \\
\hline \multicolumn{3}{|c|}{ 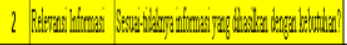 } & 1 & ? & $\gamma$ & 5 & 12 & 338 & bik \\
\hline \multicolumn{3}{|c|}{ 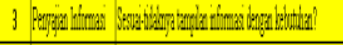 } & 1 & 4 & 8 & \$. & II & 367 & bak \\
\hline \multicolumn{3}{|c|}{ 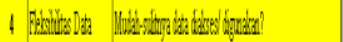 } & 1 & 6 & 31 & 5) & 13 & $3]$ & bik \\
\hline
\end{tabular}

Berdasarkan tabel 3 hasil rata-ratanya 3,64 adalah baik.

Tabel 4. Aspek Economic

\begin{tabular}{|c|c|c|c|c|c|c|c|c|c|}
\hline \multirow{2}{*}{ Heaces } & \multirow{2}{*}{ ill } & \multirow{2}{*}{ hilabur } & \multirow{2}{*}{ 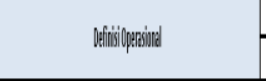 } & \multicolumn{5}{|c|}{ 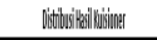 } & \multirow{2}{*}{ 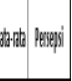 } \\
\hline & & & & 1 & l & 3 & & 5 & \\
\hline & & 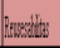 & 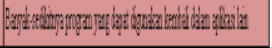 & ? & 18 & is & B & j & 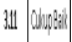 \\
\hline & 2 & (awringe & 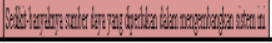 & 1 & 11 & 8 & b & 5 & 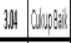 \\
\hline
\end{tabular}

Berdasarkan tabel 4 hasil rata-ratanya 3,08 adalah cukup baik.

Tabel 5. Aspek Control

\begin{tabular}{|c|c|c|c|c|c|c|c|c|}
\hline \multirow{2}{*}{ 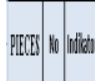 } & \multirow{2}{*}{ 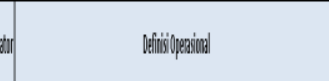 } & \multicolumn{5}{|c|}{ 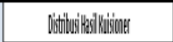 } & \multicolumn{2}{|c|}{ 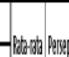 } \\
\hline & & 1 & l & 1 & $t$ & j & & \\
\hline 1 ingta & 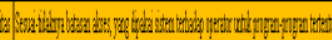 & 0 & $\mathrm{i}$ & is & \# & 1 & 34 & bi \\
\hline ligan: & 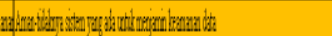 & 1 & 6 & in & i. & $\mathbb{1}$ & 318 & bik \\
\hline
\end{tabular}

Berdasarkan tabel 5 hasil rata-ratanya 3,64 adalah baik.

Tabel 6. Aspek Efficiency

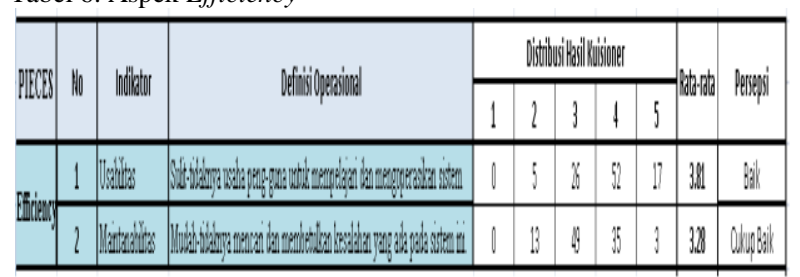

Berdasarkan tabel 6 hasil rata-ratanya 3,55 adalah baik.

Tabel 7. Aspek Services

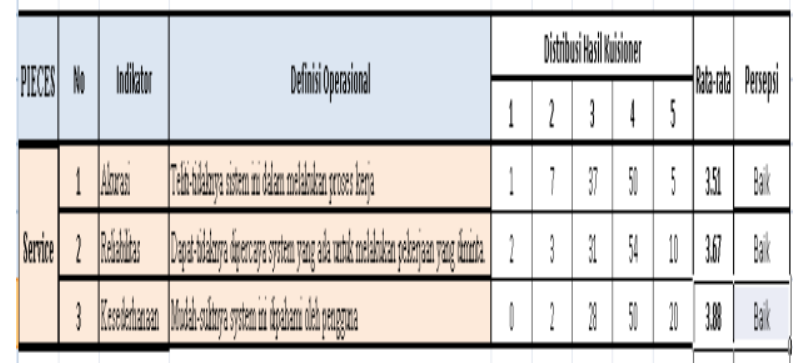

Berdasarkan tabel 7 hasil rata-ratanya 3,69 adalah baik.

Aliran Data pada diagram konteks sistem informasi SST adalah sebagai berikut terlihat seperti pada gambar 1 :

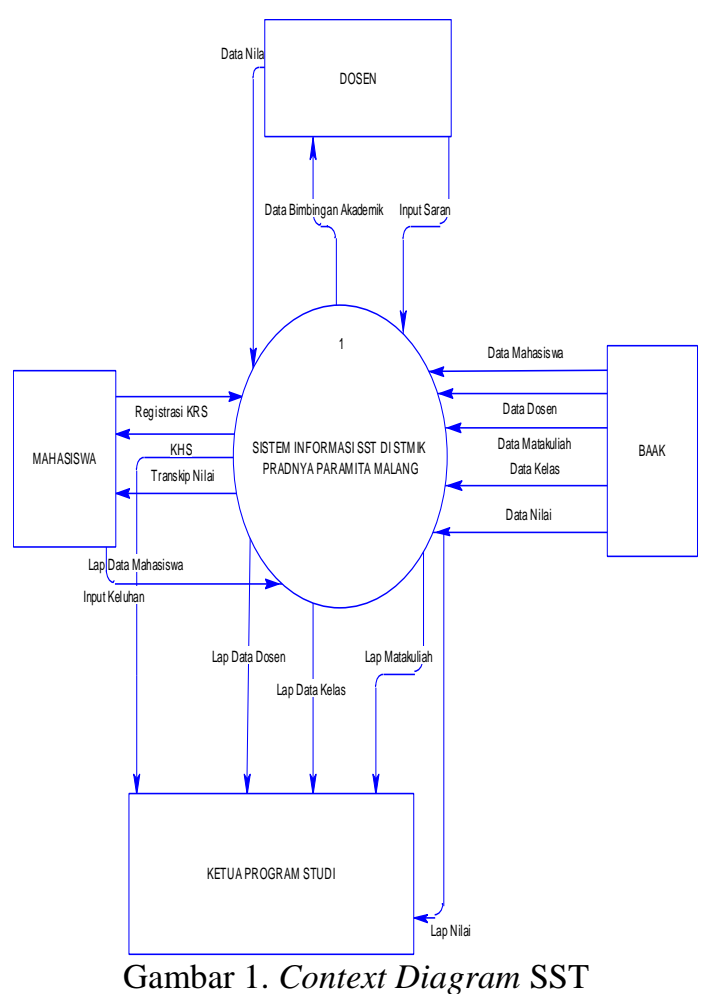

Sistem SST STMIK Pradnya Paramita Malang dengan 4 entitas yaitu mahasiswa, dosen, baak dan ketua program studi. Data Input terdiri dari Registrasi KRS, Input Keluhan, Data Nilai, Data Saran, Data Mahasiswa, Data Dosen, Data Matakuliah, Data Kelas, Data Nilai. Sedangkan Data output terdiri dari KHS, Transkip Nilai, Data Bimbingan Akademik, Laporan Mahasiswa, Laporan Dosen, Laporan Matakuliah, Laporan Kelas, Laporan Nilai.

\section{KESIMPULAN}

Hasil dari penelitian adalah adanya perbaikan, pengembangan berdasarkan analisis PIECES yang bermanfaat bagi seluruh pihak yang menggunakan SST. Berdasarkan Kuisioner yang dibagikan kepada 100 responden dengan kerangka kerja PIECES Sistem SST pada STMIK Pradnya Paramita Malang adalah baik dengan sebagian besar responden memberikan jawaban baik sebesar $47 \%$ dengan nilai 3,52, sedangkan masingmasing aspek yang terdiri dari pertama Aspek Performance (Kinerja) adalah baik dengan nilai 3,48, Kedua, aspek information (informasi) adalah baik dengan nilai 3,64, Ketiga, aspek economic (ekonomi) adalah cukup baik nilainya 3,08, Keempat, aspek control (kontrol) adalah baik dengan nilai 3,64, Kelima, aspek efficiency (Efisiensi) adalah baik dengan nilai 3,55 dan Keenam, aspek services adalah baik dengan nilai 3,69 . 


\section{DAFTAR PUSTAKA}

[1] Nuryati dan Widayanti, Nurzara A. 2015. Jurnal Manajemen Informasi kesehatan Indonesia. ISSN:2337585X, Vol.3, No.1, Maret 2015

[2] Ragil, Wukil. 2010. Pedoman Sosialisasi Prosedur Opersasi Standar. Jakarta. Mitra Wacana Media

[3] Rosa, Shalahuddin, M. 2013. Rekayasa Perangkat Lunak. Bandung: Informatika.
[4] Tullah dan Hanafri. 2014. Evaluasi Penerapan Sistem Informasi Pada Politeknik LP3I Jakarta Dengan Metode Pieces. Jurnal Sisfotek Global (ISSN : 2088 - 1762 Vol 1 / Maret 2014).

[5] Wicaksono, A. 2012. Perancangan sistem akuntansi penjualan tunai terkomputerisasi pada AL ISHBA Karpet. Jurnal Nominal / Volume I Nomor I / Tahun 2012. 